\title{
Characterization of proteins immunologically related to brain microtubule- associated protein MAP-1B in non-neural cells
}

\author{
JAVIER DIAZ-NIDO and JESÚS AVILA \\ Centro de Biología Molecular (CS/C-UAM), Universidad Autónoma, Canto Blanco, 28049 Madrid, Spain
}

\begin{abstract}
Summary
Brain microtubule-associated protein MAP-1 is composed of at least two polypeptides, MAP-1A and MAP-1B, which are among the main components of the neural cytoskeleton. Specific monoclonal and polyclonal antibodies against MAP-1B stain nuclei, mitotic spindles, centrosomes and the cytoplasmic microtubule network of different non-neural cells studied by immunofluorescence microscopy. It appears that these cells contain two proteins of $325 \mathrm{~K}$ and $220 \mathrm{~K}\left(\mathrm{~K}=10^{3} M_{\mathrm{r}}\right)$, which are immunologically related to brain MAP-1B. The $325 \mathrm{~K}$ protein, which is localized to the cytoplasmic microtubule network, the centrosome and the mitotic spindle, seems to be structurally related to neural MAP-1B, as judged from their similar peptide maps and phosphoryl-
\end{abstract}

ation patterns. The $220 \mathrm{~K}$ protein, which is localized to the nuclear matrix in interphase cells and to the mitotic spindle in dividing cells, has a proteolytic profile different from that of neural MAP-1B and is phosphorylated to a much lesser extent than the $325 \mathrm{~K}$ protein. Both proteins bind tubulin in vitro, which suggests that they may participate in microtubule assembly in vivo; the $325 \mathrm{~K}$ protein could perform such a role during the entire cell cycle, while the $220 \mathrm{~K}$ protein could be implicated in the formation of the mitotic spindle.

Key words: microtubule-associated proteins, nuclear-mitotic spindle proteins, peptide mapping, phosphorylation, neurones, non-neural cells.

\section{Introduction}

Microtubules prepared from brain extracts by cycles of temperature-dependent assembly-disassembly contain, in addition to tubulin, a group of proteins referred to as microtubule-associated proteins (MAPs) (Murphy \& Borisy, 1975), which may bind to the carboxy-terminal domain of the tubulin molecule (Serrano et al. 1984, 1985). As brain MAPs may promote microtubule assembly, stabilize the resulting microtubules and interact with other cytoskeletal elements and cell organelles (Matus, 1988; Olmsted, 1986; Vallee \& Bloom, 1984; Wiche, 1985), a role for MAPs in determining neuronal morphology and organizing the neuritic cytoplasm has been proposed (Matus, 1988). In fact, substantial amounts of MAPs are found only in nerve cells (Artlieb et al. 1985; Matus, 1988; Olmsted, 1986), which are characterized by the presence of processes stabilized by internal microtubule arrays.

However, proteins immunologically related to brain MAPs are also present, though in smaller amounts, in non-neural cells (Asai et al. 1985; Bonifacino et al. 1985; De Mey et al. 1984; Montejo de Garcini et al. 1986; Olmsted, 1986; Sato et al. 1983; Sherline \& Mascardo, 1982; Valdivia et al. 1982; Vallee et al. 1986; Wiche, 1985). It can be speculated that these non-neural MAPs may modulate microtubule assembly and stability during the cell cycle. Thus, the relative paucity of MAPs in the cytoplasmic microtubule network of non-neural cells may explain the highly dynamic behaviour of microtubules in these cells as compared to neuronal microtubules (Matus, 1988). On the other hand, the presence of some nonneural MAPs in the centrosome indicates a role for these proteins in microtubule nucleation (Bonifacino et al. 1985; Sherline \& Mascardo, 1982). Likewise, the identification of nuclear proteins immunologically related to some brain MAPs has led to the suggestion that these proteins are sequestered in the cell nucleus during interphase and may participate in the morphogenesis of the mitotic spindle after the breakdown of the nuclear envelope at the beginning of mitosis (Bonifacino et al. 1985; De Mey et al. 1984; Sato et al. 1983). However, all of these non-neural MAPs have not been characterized at a biochemical level. We report here studies of the presence of proteins related to one of the major brain MAPs, MAP-1, in both neuronal and non-neural cells.

As brain MAP-1 is really composed of two major polypeptides, MAP-1A and MAP-1B (Bloom et al. 1985; Vallee \& Bloom, 1984; Vallee et al. 1986), we have used antibodies specific for these components to determine the relationship of the MAP-1-related antigens present in non-neural cells with either MAP-1A or MAP-1B, focus- 
ing our attention on the non-neural proteins related to MAP-1B. In particular, the presence of more than one protein related to brain MAP-1B in non-neural cells, the subcellular distribution, amino acid composition, structural relationship and post-translational modifications of these proteins, together with their binding to tubulin, have been analysed.

\section{Materials and methods}

\section{Cell culture and labelling}

Primary cultures of whole brains from 18-day-old rat foetuses or cerebella from 4-day-old rat pups were used. After the brains had been removed by aseptic surgical procedures, the meninges were stripped off. The dissected tissue was rinsed in Hank's balanced salt solution, minced with a scalpel and incubated with $0.02 \%$ trypsin in a $\mathrm{Ca}^{2+}-, \mathrm{Mg}^{2+}$-free salt solution for $3-6 \mathrm{~min}$ at $37^{\circ} \mathrm{C}$. The cells were then dispersed into a suspension by repeated passage through a fire-polished Pasteur pipette. The cells were centrifuged $(500 \mathrm{~g}$ for $5 \mathrm{~min})$, resuspended in fresh culture medium and plated on culture dishes precoated with poly(L-lysine $\mathrm{HBr}$ ) (Sigma, cat. P-1399). The culture medium consisted of Dulbecco's modified Eagle medium (DME) supplemented with $10 \%$ foetal calf serum, and $0.3 \%$ glucose. To obtain neurone-enriched cultures, cells were treated for $24 \mathrm{~h}$ with cytosine arabinoside 3 days after plating and then transferred to a culture medium consisting of DME supplemented with $2 \%$ foetal calf serum, $5 \mu \mathrm{g} \mathrm{m}^{-1}$ insulin, $100 \mu \mathrm{g} \mathrm{ml}^{-1}$ transferrin, and $0.3 \%$ glucose.

Primary cultures of human skin fibroblasts were a generous gift from C. Hernández (Centro de Biología Molecular, Madrid).

Mouse neuroblastoma cells (clones NIE 115 and N2A) rat glioma cells (C6), rat kidney fibroblasts (NRK), Chinese hamster ovary cells (CHO) and potoroo kidney cells (PTK-2) were cultured in DME supplemented with $10 \%$ foetal calf serum.

Mitotic cells were collected by shaking them off the culture dish after nocodazole treatment.

Cells were labelled for $20 \mathrm{~h}$ in culture medium lacking methionine to which $\left[{ }^{35} \mathrm{~S}\right]$ methionıne (Amersham) was added to $0.5 \mathrm{mCi} \mathrm{ml}^{-1}$ Phosphate labelling was performed for $20 \mathrm{~h}$ with $1 \mathrm{mCi} \mathrm{ml}^{-1}\left({ }^{32} \mathrm{PO}_{4}\right.$, Amersham) as described (Draz-Nido et al. 1988).

\section{Immunofluorescence microscopy}

Cells grown on coverslips were fixed in methanol for $10 \mathrm{~min}$ at $-20^{\circ} \mathrm{C}$ and washed with phosphate-buffered saline (PBS) $(140 \mathrm{~mm}-\mathrm{NaCl}, 20 \mathrm{~mm}$-sodium phosphate, $\mathrm{pH} 7 \cdot 5)$. The coverslips were incubated for $1 \mathrm{~h}$ at room temperature with either a monospecific polyclonal antibody raised in rabbit or a mouse monoclonal antibody against MAP-1B (see Table 1). The coverslips were then washed in PBS and incubated for $30 \mathrm{~min}$ at room temperature with either a rhodamine-conjugated goat

Table 1. Antibodies used in this study

\begin{tabular}{ll}
\hline 1B-1 & $\begin{array}{c}\text { Mouse monoclonal antibody (IgG1) to MAP-1B (Bloom et } \\
\text { al. 1985; Vallee et al. 1986) } \\
\text { Mouse monoclonal antibody (IgM) to phosphorylated } \\
\text { 1B-3 }\end{array}$ \\
$\begin{array}{l}\text { MAP-1A and MAP-1B (Luca } \text { et al 1986; Vallee } \text { et al. } \\
\text { 1986) }\end{array}$ \\
$\begin{array}{l}\text { Rabbit polyclonal antibody to MAP-1B } \\
100\end{array}$ & $\begin{array}{l}\text { Rabbit polyclonal antibody to MAP-1B } \\
\text { Rabbit polyclonal antibody to MAP-1A }\end{array}$ \\
\hline
\end{tabular}

anti-rabbit immunoglobulin (TAGO, Burlingame, $\mathrm{CA}$ ) or a fluorescein-conjugated goat anti-mouse immunoglobulin (TAGO, Burlingame, CA) at a dilution of $1: 80$. The coverslips were mounted with glycerol/PBS $(9 / 1, v / v)$ and examined using a Nikon fluorescence microscope.

\section{Cell fractionation}

Cells were washed with and scraped into $10 \mathrm{~mm}$-sodium phosphate $(\mathrm{pH} 7 \cdot 0)$ containing $0.32 \mathrm{M}$-sucrose, $2 \mathrm{~mm}-\mathrm{MgCl}_{2}$, $10 \mu \mathrm{g} \mathrm{ml}^{-1}$ aprotinin, $10 \mu \mathrm{g} \mathrm{ml}^{-1}$ leupeptin and $1 \mathrm{~mm}$-phenylmethylsulphonyl fluoride (PMSF). The cells were then collected by low-speed centrifugation and extracted with $0.5 \%$ Triton X-100 (in the same buffer as above) for $30 \mathrm{~min}$ at $4^{\circ} \mathrm{C}$. The resulting supernatant was referred to as the cytoplasmic fraction. The particulate fraction was resuspended in $10 \mathrm{~mm}$ sodium phosphate ( $\mathrm{pH} 7 \cdot 0$ ) containing $140 \mathrm{~mm}-\mathrm{NaCl}, 10 \mathrm{~mm}$ EDTA, $10 \mu \mathrm{g} \mathrm{ml}^{-1}$ aprotinin, $10 \mu \mathrm{g} \mathrm{ml}^{-1}$ leupeptin, and $1 \mathrm{~mm}$ PMSF, and digested with 100 units $m$ of preboiled RNase $A$ and RNase $\mathrm{T}_{1}$ (Sigma) for $30 \mathrm{~min}$ at $4^{\circ} \mathrm{C}$. Subsequently, $\left(\mathrm{NH}_{4}\right)_{2} \mathrm{SO}_{4}$ was added to a concentration of $1 \mathrm{M}$ and the incubation was continued for $15 \mathrm{~min}$ at $4^{\circ} \mathrm{C}$. Finally, the sample was subjected to low-speed centrifugation. The resulting supernatant was referred to as soluble nuclear fraction and the particulate fraction as residual insoluble fraction. This protocol was also applied to the in situ extraction of cells attached to the culture dish prior to fixation and immunofluorescence microscopy.

\section{Protein preparations}

Microtubule protein from pig or rat brain was prepared by temperature-dependent cycles of assembly-disassembly according to Shelanski et al. (1973) and stored in buffer A (0.1 M-4-morpholinoethane sulphonic acid (Mes), $0.5 \mathrm{~mm}$ $\mathrm{MgCl}_{2}, 2.5 \mathrm{~mm}$-EGTA, pH 6.4), containing $50 \%$ glycerol at $-70^{\circ} \mathrm{C}$. Tubulin depleted of MAPs was obtained by phosphocellulose chromatography as described by Weingarten et al. (1975).

\section{Immunoprecipitation}

Samples were brought to $100 \mu \mathrm{l}$ with immunoprecipitation buffer (50 mm-Tris-HCl (pH 7.5), 2 mm-EGTA, $150 \mathrm{~mm}$ $\mathrm{NaCl}, 20 \mathrm{~mm}-\mathrm{NaF}, 1 \%$ Nonidet $\mathrm{P}-40,0.5 \%$ sodium deoxycholate, $0.1 \%$ SDS, $1 \mathrm{mM}-\mathrm{ATP}, 10 \mu \mathrm{g} \mathrm{m}^{-1}$ aprotinin, $10 \mu \mathrm{g} \mathrm{ml}^{-1}$ pepstatın A, $10 \mu \mathrm{g} \mathrm{ml}^{-1}$ leupeptin and $1 \mathrm{~mm}$-PMSF) and preadsorbed for $5 \mathrm{~min}$ with $100 \mu \mathrm{l}$ of $10 \%$ Staphylococcus aureus (Pansorbin). After centrifugation to remove $\dot{S}$. aureus, $100 \mu \mathrm{l}$ of either hybridoma-conditioned culture medium or polyclonal antiserum to MAP-1B (diluted 1:200 in immunoprecipitation buffer) was added. The sample was incubated for $2 \mathrm{~h}$ on ice. When using hybridoma-conditioned culture medium, $4 \mu \mathrm{l}$ of a rabbit anti-mouse immunoglobulin (IgA, IgG and $\operatorname{IgM}$ ) was added and a reincubation of $1 \mathrm{~h}$ on ice was performed. Subsequently, $100 \mu$ of $10 \% S$. aureus was added and the sample was incubated for $10 \mathrm{~min}$ on ice. The sample was then centrifuged and the $S$. aureus pellet washed five times in immunoprecipitation buffer. The $S$. aureus pellet was finally resuspended in SDS sample buffer $(1 \%$ SDS, $2 \%$ 2-mercaptoethanol, $10 \%$ glycerol) and subjected to SDS-PAGE (polyacrylamide gel electrophoresis).

\section{Gel electrophoresis}

SDS-PAGE was performed according to the procedure of Laemmli (1970) and gels were stained with Coomassie Blue as indicated by Fairbanks et al. (1981). Labelled proteins were detected by autoradiography of dried gels exposed to Kodak XOmat films. 


\section{Westem blotting}

Samples electrophoresed on SDS-polyacrylamide gels were transferred to nitrocellulose paper according to the method of Towbin et al. (1979). As a second antibody, a peroxidaseconjugated goat anti-mouse IgM was used. The peroxidase reaction was developed using $\alpha$-chloronaphthol and hydrogen peroxide as substrate.

\section{Tubulin binding assay}

Proteins were assayed for tubulin binding following the method of Kremer et al. (1988). Briefly, samples electrophoresed on SDS-polyacrylamide gels were transferred to nitrocellulose paper. The paper was blocked with buffer A $(0 \cdot 1 \mathrm{M}-\mathrm{Mes}$, $0.5 \mathrm{~mm}-\mathrm{MgCl}_{2}, 2.5 \mathrm{~mm}$-EGTA, pH 6.4) containing $2 \%$ bovine serum albumin for $2 \mathrm{~h}$ at room temperature, and then incubated with $4 \mu \mathrm{g} \mathrm{ml}^{-1}$ tubulin in buffer A plus $2 \%$ bovine serum albumin and $20 \%(\mathrm{w} / \mathrm{v})$ sucrose for $2 \mathrm{~h}$ at room temperature. The paper was subjected to three 10 -min washes with buffer $A$ and fixed for $30 \mathrm{~min}$ in $0.5 \%$ formaldehyde, after which aldehyde groups were masked by incubation in $2 \%$ glycine for $30 \mathrm{~min}$. After extensive washing, bound tubulin was revealed by immunoblotting with anti- $\alpha^{-}$and anti- $\beta$-tubulin monoclonal antibodies (Amersham).

\section{Copolymerization assay}

Tubulin or subtilisin-digested tubulin was polymerized at $30^{\circ} \mathrm{C}$ for $20 \mathrm{~min}$ in the presence of $1 \mathrm{~mm}$-GTP and $10 \mu \mathrm{m}$-taxol as described by Serrano et al. (1984). The $220 \mathrm{~K}\left(\mathrm{~K}=10^{3} M_{\mathrm{r}}\right)$ protein (purified from an immunoprecipitate by gel filtratıon in the presence of $0.1 \%$ SDS and renatured after extensive dialysis against a suspension of $\mathrm{Bio}-\mathrm{Rad} \mathrm{AD} 11 \mathrm{~A} 8$ resin in buffer A) was added to either of these proteins and incubated at $30^{\circ} \mathrm{C}$ for $20 \mathrm{~min}$. The samples were layered onto a cushion of $40 \%(\mathrm{w} / \mathrm{v})$ sucrose in buffer $\mathrm{A}$ and centrifuged in a Beckman airfuge $(7 \mathrm{~min}$ at $100000 \mathrm{~g})$.

\section{Limited proteolysis}

A rat brain MAP preparation, obtained by phosphocellulose chromatography as described by Weingarten et al. (1975), and a soluble rat liver nuclear fraction, obtained after nuclease digestion and high-salt extraction as described before, were mixed with $\alpha$-chymotrypsin ( $5 \mu \mathrm{g}$ per $2.5 \mathrm{mg}$ of protein) and incubated at $30^{\circ} \mathrm{C}$ for $20 \mathrm{~min}$. The resulting peptides were fractionated on a $18 \%$ polyacrylanide gel and transferred to nitrocellulose paper. The peptides recognized by the antibody to MAP-1B (81) were revealed by immunoblotting.

\section{Peptide mapping}

Extensive trypsin digestions were performed as desrribed by Hermann et al. (1985). The resulting peptides, in $0.1 \%$ trifluoroacetic acid, were applied to a reverse-phase HPLC column (NOVA PAK C 18) and fractionated using a $0-80 \%$ acetonitrile gradient in $0.1 \%$ trifluoroacetic acid with a flow rate of $0.5 \mathrm{ml} \mathrm{min}^{-1}$

\section{Amino acid analysis}

Proteins were electroeluted from preparative SDS-polyacrylamide gels; elution buffer consisting of $50 \mathrm{~mm}-\mathrm{NH}_{4} \mathrm{HCO}_{3}, 0.1 \%$ SDS, $0.1 \mathrm{~mm}$-PMSF, $5 \mathrm{~mm}$-EDTA. Following electroelution, two volumes of $1 \%$ triethylamine was added to the sample, which then was lyophilized. The lyophilate was resuspended in $5 \%$ glacial acetic acid and relyophilized. Finally, protein was precipitated by overnight incubation with acetone at $-20^{\circ} \mathrm{C}$, followed by low speed centrifugation. The pellets were hydrolysed with $6 \mathrm{M}-\mathrm{HCl}$ under vacuum at $108^{\circ} \mathrm{C}$ for $24 \mathrm{~h}$ and analysed on a Beckman 121L amino acid analyser.

\section{Results}

Distribution of antigens related to brain MAP-1B in cultured neural and non-neural cells

The localization of brain MAP-1B and related antigens has been studied by immunofluorescence microscopy using different polyclonal and monoclonal antibodies raised against MAP-1B (81, 100 and 1B-1). Fig. 1 shows an example of the reaction of the antibodies used with brain MAP-1B. In addition to these antibodies, a monoclonal antibody that recognizes a phosphorylated epitope common to MAP-1A and MAP-1B (1B-3) and, as a control, a polyclonal antibody to MAP-1A (313) were used (see Table 1 in Materials and methods).

Primary cultures of rat brain cells, containing both neurones and glial cells, have been used for the immunofluorescence microscopy analyses.

In neurones, both the cell body and the processes are very intensely immunostained with all antibodies to MAP-1B tested (Fig. 2), as was reported for the monoclonal antibody 1B-1 (Bloom et al. 1985). A similar
A

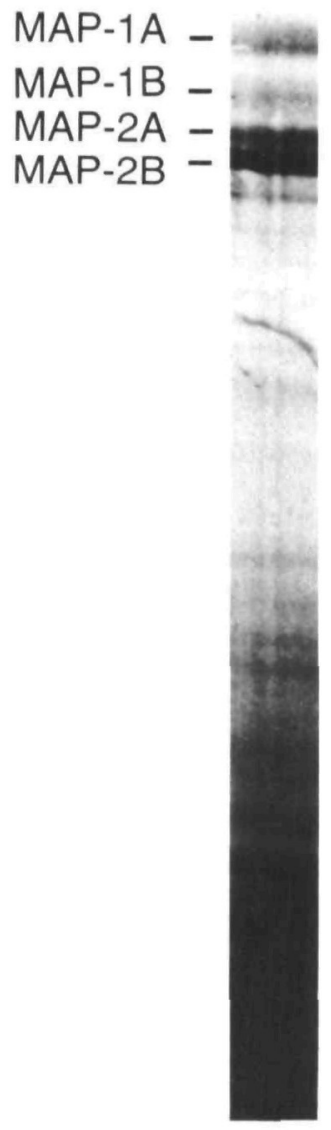

Fig. 1. Immunoblotting analysis showing the reactions of antibody 81 with brain MAP-1B. Rat brain nicrotubule protein was subjected to SDS-PAGE, transferred to nitrocellulose and probed with the antibody 81 . A. The Coomassie Blue-stained pattern of rat brain microtubule protein; and $\mathrm{B}$, the corresponding immunoblot. 

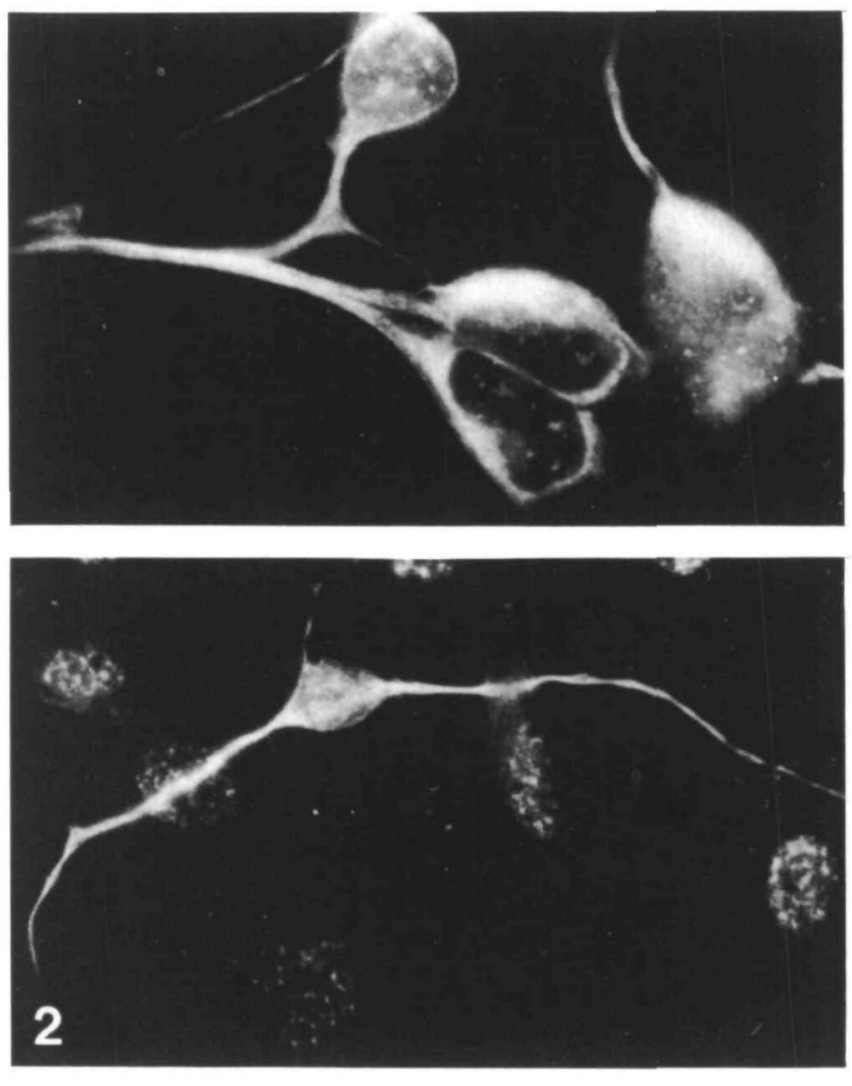

staining pattern is also observed with the antibody to MAP-1A (not shown), in accordance with previous results of Vallee et al. (1986). In addition to the cytoplasmic staining corresponding to the microtubule network, monoclonal antibody $1 \mathrm{~B}-3$ and the antiserum 81 revealed a faint immunostaining of intranuclear dots (Fig. 2).

The same pattern as that observed for rat brain neurones in primary culture is found in mouse neuroblastoma cells (N2A and NIE-115), although the nuclear immunostaining is less apparent in these cells. A prominent staining of axon-like processes is also observed in neuroblastoma cells that are induced to differentiate by serum deprivation (not shown). These processes are brightly stained by all the antibodies to MAP-1B tested, while they are barely stained by antibodies to MAP-1A or MAP-2 (M. A. Hernández, unpublished results).

$A$ rather different pattern is seen within rat brain glial cells (Fig. 3). The MAP-1B immunostaining of the cytoplasmic microtubule network is markedly less intense in glial cells than it is in neurones, with all antibodies tested. This cytoplasmic staining is more apparent in fully differentiated astrocytes, which have extended numerous processes, than it is in proliferating undifferentiated cells. In proliferating glial cells, mitotic spindles appear very intensely stained with all antibodies to MAP$1 \mathrm{~B}$ (Fig. 3).

On the other hand, all glial cells exhibit a prominent nuclear staining with the antibodies $1 \mathrm{~B}-3$ and 81 . This
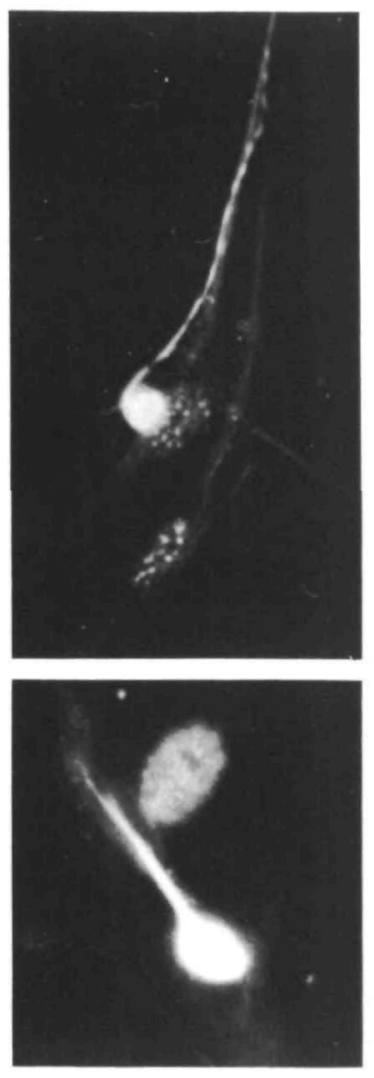

Fig. 2. Immunofluorescent staining pattern of neurones from primary cultures of rat brain incubated with a polyclonal antibody to MAP-1B (81).

Neurones are usually in close contact with glial cells, whose nuclei are also visualized in these micrographs.

nuclear staining consists of bright fluorescent intranuclear dots or speckles that are excluded from the nucleoli (Fig. 3).

The same pattern as that described for glial cells, i.e. less-intense cytoplasmic staining and stronger nuclear immunoreactivity than in neurones, is also observed in rat glioma cells and other non-neural cells, including primary cultures of human skin fibroblasts, and established cell lines such as NRK and $\mathrm{CHO}$, with the antibody 81 (Fig. 4).

A fluorescent spot near the nucleus is also observed with all antibodies to MAP-1B (1B-3, 81, 100 and 1B-1) in non-neural cells. This spot corresponds to the microtubule-organizing centre (MTOC), as determined by double immunofluorescence studies with an antiserum recognizing centrosomes ( $\mathrm{J}$. Dominguez, unpublished results) or with antibodies to tubulin in cells previously treated with nocodazole and then transferred to culture medium lacking the drug (data not shown).

Like neural cells, non-neural cells exhibit a notably different pattern when probed with the polyclonal antibody to MAP-1A. Our antibody to MAP-1A mainly stains a diffuse perinuclear region and does not react with intranuclear dots or the MTOC (not shown). This suggests that the intranuclear staining observed by other authors using antibodies raised against whole MAP-1 is probably due to a MAP-1B-related antigen.

The finding that this nuclear antigen is not recognized 

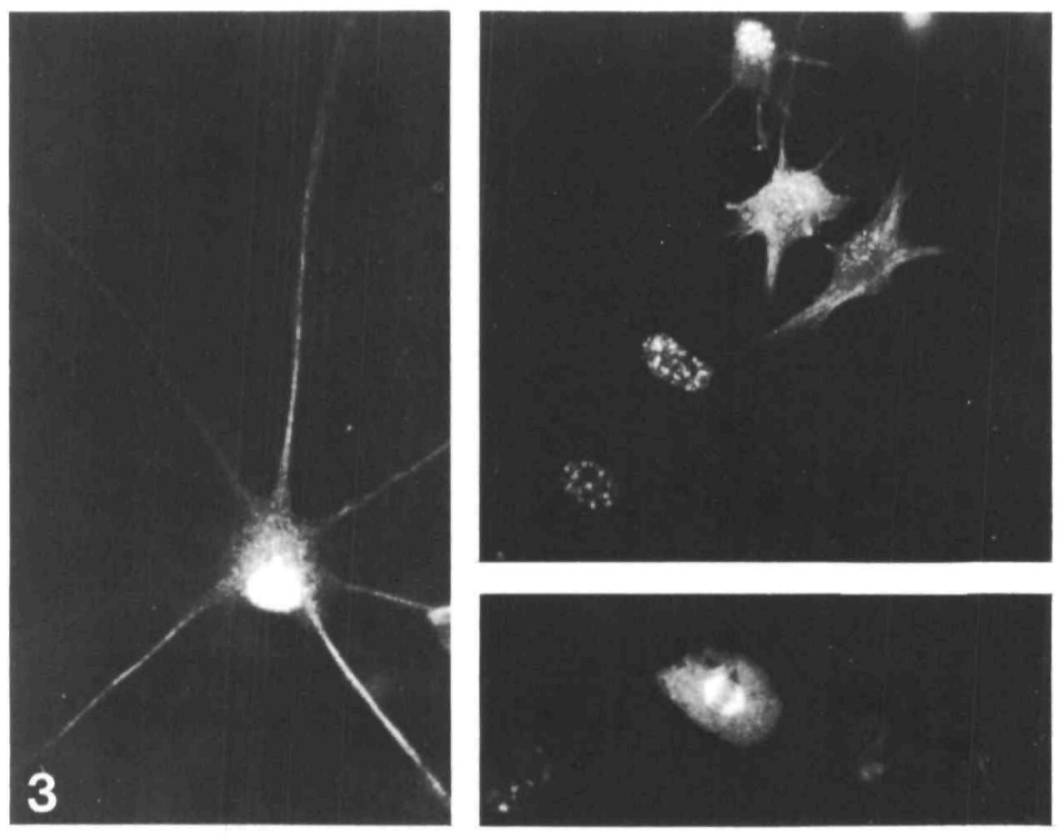

Fig. 3. Immunofluorescent staining pattern of glial cells from primary cultures of rat brain incubated with a polyclonal antibody to MAP-1B (81).
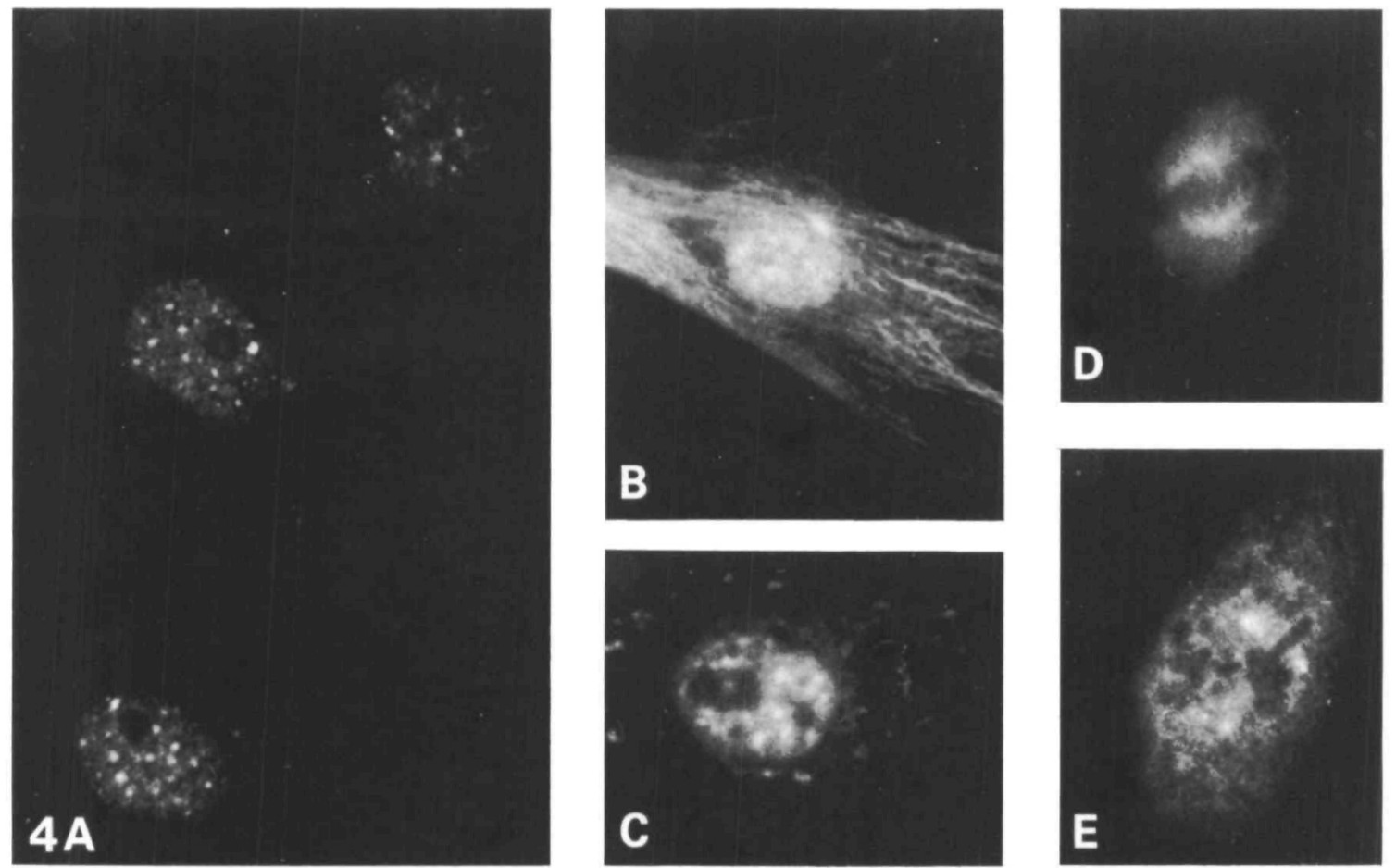

Fig. 4. Immunofluorescent staining pattern of different non-neural cells incubated with the polyclonal antibody 81 against MAP-1B, A. PTK-2 cells; B, a human skin fibroblast; C, a CHO cell treated with colcemid; D, a mitotic PTK-2 cell; and $\mathrm{E}$, another mitotic cell after microtubule depolymerization.

by some antibodies to brain MAP-1B (1B-1 and 100), which react with cytoplasmic microtubules and the MTOC, suggests that there are different proteins immunologically related to MAP-1B in non-neural cells. One of these would be localized to the nucleus and another to the cytoplasmic microtubules and the MTOC.

The immunofluorescence staining pattern of the MAP$1 \mathrm{~B}$ antibodies in PTK-2 rat kangaroo cells is somewhat different (see Fig. 4A). The interphase-mitosis transition in PTK-2 cells is shown in Fig. 5. During interphase, both the nucleus and the MTOC are stained but there is no staining of the cytoplasmic microtubule network. In early prophase, the labelling remains within the nucleus, and is excluded from the condensing chromatin. In late prophase, the staining is confined to between the chromosomes. Eventually, in metaphase, the 

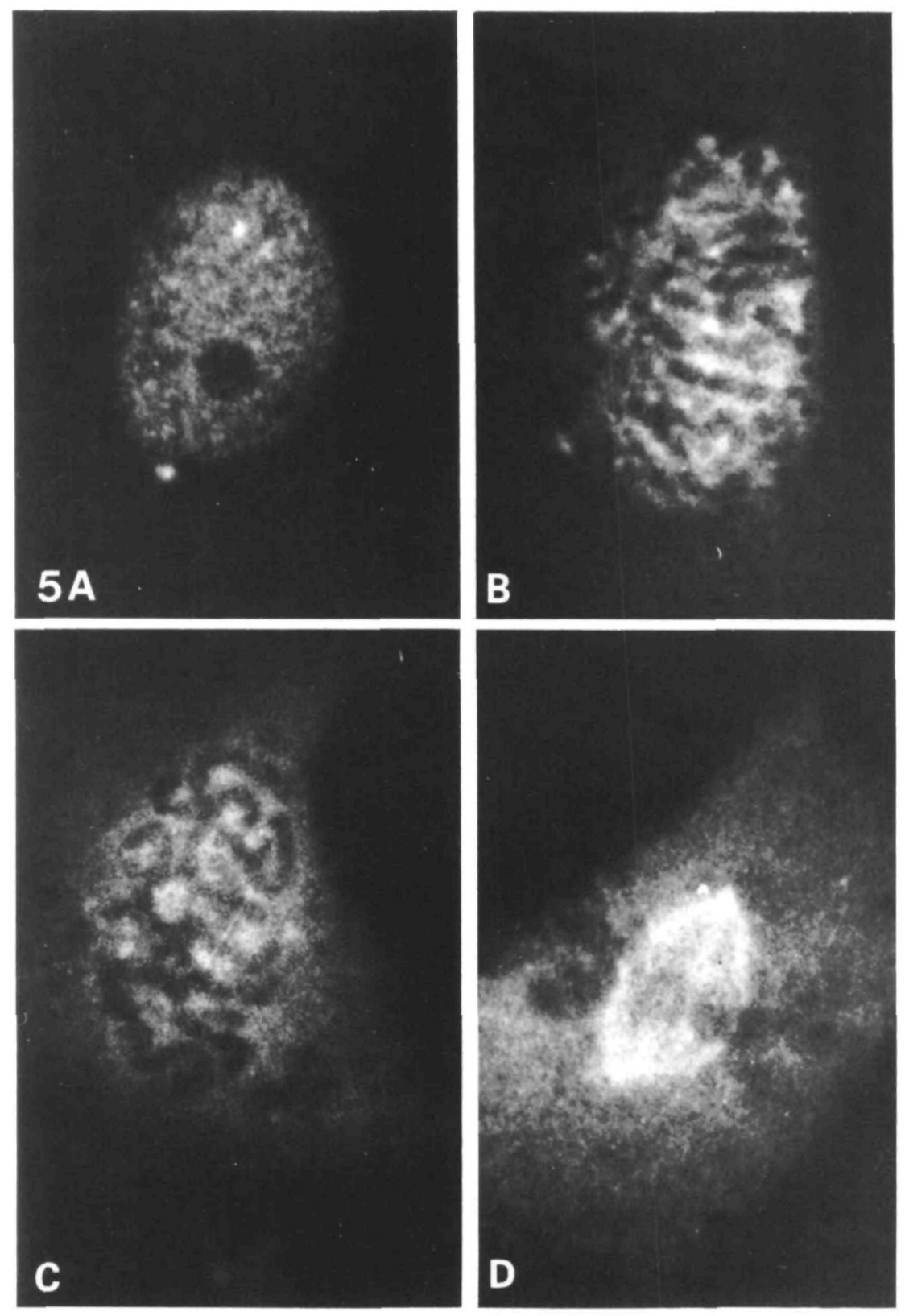

Fig. 5. Immunofluorescent distribution of MAP-1B-related antigens during the first stages of mitosis in PTK-2 cells using the polyclonal antibody 81 . Shown are an interphase cell (A), an early prophase cell (B), a late prophase cell (C), and a metaphase cell (D).

staining is diffusely distributed throughout the cytoplasm; the most intense fluorescence is present at the mitotic spindle, with an apparent preference for the mitotic poles and the kinetochore-to-pole microtubules.

When mitotic cells are treated with colcemid or cold $\mathrm{Ca}^{2+}$ solutions to depolymerize microtubules, the staining of the mitotic spindle microtubules is dispersed, whereas the staining of the mitotic poles remains (Fig. 4). This suggests that the antigens related to brain MAP-1B are actually bound to mitotic microtubules.

A summary of these immunocytochemical data is shown in Table 2.

\section{Association of the nuclear MAP-IB-related antigen with} the nuclear matrix

Except for its association with the mitotic apparatus, the anti-MAP-1B nuclear staining pattern resembles that of some proteins that are associated with ribonucleoprotein
(RNP) particles of the nuclear matrix. A dot-like distr1bution pattern with exclusion from the nucleoli in interphase nuclei is observed, which becomes dispersed throughout the cytoplasm, with the exception of the chromatin regions, during mitosis (Smith et al. 1986; Spector \& Smith, 1986; Verheijen et al. 1986). Thus, the localization of the nuclear antigen related to MAP-1B in non-neural cells may be compatible with a possible association of such a protein with RNPs. To test for an interaction of the nuclear MAP-1B-related protein with any nucleic acid-containing structure present in the nucleus, digestion with RNase or DNase followed by extraction with a high ionic strength buffer was performed. Fig. 6 shows that treatment of PTK-2 cells in situ with RNase in the presence of EDTA and high-salt extraction abolished the nuclear MAP-1B staining, without greatly affecting the staining of the MTOC. However, DNase digestion followed by high-salt extraction 
Table 2. Immunofluorescence microscopy

\begin{tabular}{|c|c|c|c|c|c|c|}
\hline & & \multicolumn{3}{|c|}{ Antibodies to MAP-1B } & \multirow{2}{*}{$\begin{array}{c}\text { Antibody to } \\
\text { phosphorylated } \\
\text { MAP-1A, MAP-1B } \\
\text { 1B-3 }\end{array}$} & \multirow{2}{*}{$\begin{array}{c}\text { Antibody to } \\
\text { MAP-1A } \\
313\end{array}$} \\
\hline & & 10 & $1 \mathrm{~B}-1$ & 81 & & \\
\hline \multirow{3}{*}{$\begin{array}{l}\text { Brain neurones, } \\
\text { neuroblastoma cells } \\
\text { (N2A, NIE-115) }\end{array}$} & $\begin{array}{l}\text { Cell body and neuritic } \\
\text { microtubules }\end{array}$ & +++ & +++ & +++ & +++ & ++ \\
\hline & Intranuclear speckles & - & - & + & + & - \\
\hline & Diffuse perinuclear region & - & - & - & - & ++ \\
\hline \multirow{5}{*}{$\begin{array}{l}\text { Brain glial cells, } \\
\text { glioma cells, } \\
\text { skin fibroblasts, } \\
\text { NRK and CHO cells }\end{array}$} & Cytoplasmic microtubules & ++ & ++ & ++ & + & ++ \\
\hline & Mitotic spindle & +++ & +++ & +++ & ++ & + \\
\hline & MTOC and mitotic poles & +++ & +++ & +++ & +++ & + \\
\hline & Intranuclear speckles & - & - & +++ & +++ & - \\
\hline & Diffuse perinuclear region & - & - & - & - & +++ \\
\hline \multirow[t]{5}{*}{ PTK-2 cells } & Cytoplasmic microtubules & \pm & \pm & - & - & \pm \\
\hline & Mitotic spindle & + & + & +++ & ++ & \pm \\
\hline & MTOC and mitotic poles & +++ & +++ & +++ & +++ & + \\
\hline & Intranuclear speckles & - & - & +++ & +++ & - \\
\hline & Diffuse perinuclear region & - & - & - & - & +++ \\
\hline
\end{tabular}
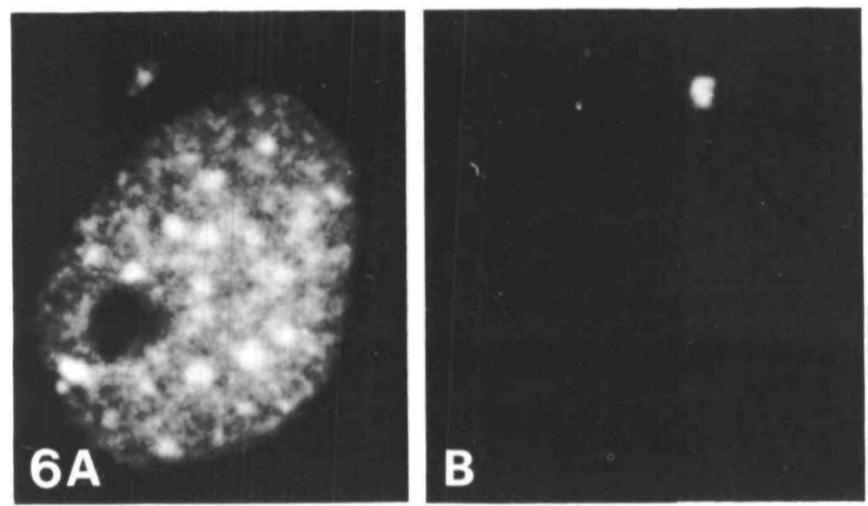

Fig. 6. Immunofluorescent staining pattern of PTK-2 cells incubated with a polyclonal antibody to MAP-1B (81) after nuclear matrix extraction. Nuclear matrix was solubilized by treatment with Triton X-100, extensive in situ RNA digestion in the presence of EDTA and high-salt extraction. A. An intact cell; and $\mathrm{B}$, an extracted cell.

hardly influences the nuclear MAP-1B staining (not shown). This suggests that the nuclear MAP-1B-related antigen may be associated with the RNP network of the nuclear matrix during interphase. Moreover, treatment with RNase may be used as a tool for solubilizing and isolating such nuclear antigen.

\section{Distribution of brain MAP-IB-related proteins after cell fractionation of non-neural cells}

Immunofluorescence studies indicate the presence of MAP-1B-related proteins in three different localizations, the nucleus, cytoplasmic microtubules and the MTOC. These different locations and the selective solubilization of the nuclear antigen upon RNase treatment suggest the existence of several MAP-1B-related proteins in nonneural cells. These proteins were identified by cell fractionation and immunoprecipitation of the whole cell extract, the cytoplasmic fraction, the nuclear fraction and the insoluble fraction obtained from NRK cells as described in Materials and methods. Fig. 7A shows that a whole cell extract from NRK cells labelled with $\left[{ }^{35} \mathrm{~S}\right]$ methionine contains two proteins immunoprecipitated by polyclonal antibody 81 . These two proteins showed apparent molecular masses of $325 \times 10^{3}$ and $220 \times 10^{3}$, as determined by a Ferguson plot (Fig. 8). The apparent molecular mass of the $325 \mathrm{~K}$ protein is the same as that of brain MAP-1B. While the molecular mass of the $220 \mathrm{~K}$ protein does not depend on acrylamide gel concentration, both MAP-1B and the $325 \mathrm{~K}$ protein have anomalous behaviour in SDS-PAGE, as has been described for brain MAP-2 (Hernández et al. 1986). Cell fractionation studies indicate that the soluble cytoplasmic fraction is enriched in the $325 \mathrm{~K}$ protein (Fig. 7B), while the nuclear fraction is enriched in the $220 \mathrm{~K}$ protein (Fig. 7C). The residual insoluble fraction contains a minor proportion of the $325 \mathrm{~K}$ protein, as well as trace amounts of the $220 \mathrm{~K}$ protein (Fig. $7 \mathrm{D}$ ). It also appears that the soluble cytoplasmic fraction of mitotic NRK cells previously treated with nocodazole contain three MAP$1 \mathrm{~B}$-related antigens: a $325 \mathrm{~K}$, a $260 \mathrm{~K}$ and a $220 \mathrm{~K}$ protein (Fig. 7E). The amount of the $220 \mathrm{~K}$ protein in soluble mitotic fractions is notably higher than in the soluble cytoplasmic fraction from interphase cells. This agrees well with immunofluorescence data that indicate an association of the nuclear antigen with mitotic spindles. The $260 \mathrm{~K}$ protein, also found in interphase cells, is present in variable amounts from preparation to preparation, and seems to be a proteolytic product of the $325 \mathrm{~K}$ protein as judged from their highly similar peptide maps (not shown). A similar proteolytic fragment of MAP-1B is also found in some brain microtubule preparations. When the whole cell extract from NRK cells is immunoprecipitated with antibody 100 , only the $325 \mathrm{~K}$ protein is found (Fig. 7F).

These results, together with the immunofluorescence data, suggest that the $325 \mathrm{~K}$ protein is associated with the centrosome and also with cytoplasmic microtubules, whereas the $220 \mathrm{~K}$ protein is associated with the nuclear 


\section{K A \\ 325-}

B

260-

$220-$

B $\quad$ C $\quad D \quad E$
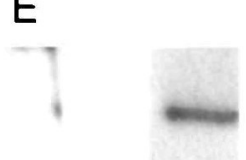

Fig. 7. Identification of non-neural MAP-1B-related antigens in different cell fractions. NRK fibroblasts were grown in the presence of $\left[{ }^{35} \mathrm{~S}\right]$ methionine. Mitotic cells were separated from interphase cells by shaking after nocodazole treatment. Interphase cells were homogenized in immunoprecipitation buffer with a teflon-glass homogenizer, and the resulting whole cell extract was subjected to immunoprecipitation, with the polyclonal antibody 81 .

The immunoprecipitate was fractionated by SDS-PAGE in a $6 \%$ polyacrylamide gel containing $4 \mathrm{M}$-urea and the corresponding autoradiography is shown in $A$. Alternatively, interphase cells were scraped off the culture dish and extracted with Triton $X-100$. The resulting soluble cytoplasmıc fraction was immunoprecipitated with the polyclonal antibody 81 and the corresponding autoradiography is shown in B. The nuclear proteins were then extracted as described in Materials and methods, and

immunoprecipitated. The corresponding autoradiography is shown in $\mathrm{C}$. The residual fraction containing the insoluble cytoskeleton was solubilized with SDS and immunoprecipitated with the polyclonal antibody 81 . The corresponding autoradiography is shown in D. Mitotic cells were treated with nocodazole and extracted with Triton X-100, and the resulting soluble fraction was immunoprecipitated with the polyclonal antibody 81 . The corresponding autoradiography is shown in E. F. The immunoprecipitate obtained from a whole cell extract of interphase NRK cells with the polyclonal antibody 100 .

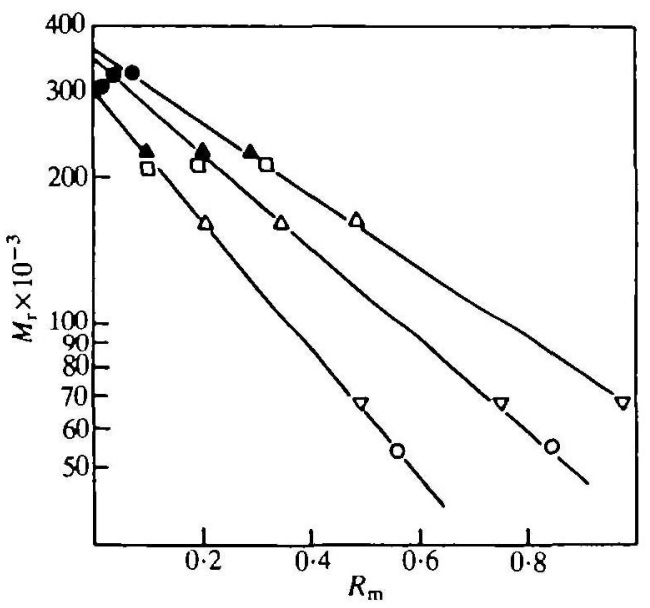

Fig. 8. Determination of apparent molecular mass of nonneural MAP-1B-related antigens by SDS-gel electrophoresis. The plot of $M_{\mathrm{r}}$ versus relative mobility $\left(R_{\mathrm{m}}\right)$ at three concentrations of polyacrylamide $(7.5 \%, 6 \%$ and $5 \%)$ is shown. (O) Overlapping data obtained for both neural MAP-1B and non-neural $325 \mathrm{~K}$ protein; $(\boldsymbol{\Delta})$ non-neural $220 \mathrm{~K}$ protein; $(O) 210 \mathrm{~K}$ pig brain neurofilament protein; $(\triangle) 160 \mathrm{~K}$ pig brain neurofilament protein; $(\nabla) 68 \mathrm{~K}$ pig brain neurofilament protein; and $(\square)$ data for $\beta$-tubulin. matrix. As judged from Fig. 7E, both proteins are associated with the mitotic spindle.

\section{Amino acid composition and quantification of $325 \mathrm{~K}$ and $220 \mathrm{~K}$ proteins}

These proteins were fractionated by gel electrophoresis, eluted from the gel and their amino acid content was determined. Table 3 shows a similar composition for both proteins. As they have similar methionine contents, a comparison of the amounts present in immunoprecipitates from different cell extracts, shown in Fig. 9, can be established. Thus, the $220 \mathrm{~K}$ protein appears to be slightly more abundant than the $325 \mathrm{~K}$ protein in the whole cell extract from NRK cells. However, a large amount of the $220 \mathrm{~K}$ protein and only a trace amount of the $325 \mathrm{~K}$ protein are found in immunoprecipitates from whole PTK-2 cell extracts. In extracts from primary cultures of rat neurones the amount of the $325 \mathrm{~K}$ protein (MAP-1B) is notably higher than that of the $220 \mathrm{~K}$ protein, thus confirming the immunocytochemical data.

\section{Differences between $325 K$ and $220 K$ proteins}

In addition to their different electrophoretic mobilities, their different reaction with antibodies 100 and $1 \mathrm{~B}-1$, and 
Table 3. Amino acid composition of rat $325 \mathrm{~K}$ and $220 \mathrm{~K}$ proteins

\begin{tabular}{lrr}
\hline & \multicolumn{2}{c}{ Amount $(\mathrm{mol} / 100 \mathrm{~mol})$} \\
\hline Amino acid & $325 \mathrm{~K}$ & $220 \mathrm{~K}$ \\
\hline Glx & $7 \cdot 9$ & $8 \cdot 0$ \\
Thr & $14 \cdot 5$ & $14 \cdot 9$ \\
Ser & $4 \cdot 6$ & $4 \cdot 3$ \\
Pro & $7 \cdot 4$ & $10 \cdot 0$ \\
Gly & $5 \cdot 2$ & $5 \cdot 7$ \\
Ala & $19 \cdot 2$ & $17 \cdot 2$ \\
Val & $6 \cdot 1$ & $4 \cdot 9$ \\
Met & $5 \cdot 7$ & $4 \cdot 2$ \\
Iso & $1 \cdot 4$ & $1 \cdot 6$ \\
Leu & $3 \cdot 6$ & $2 \cdot 9$ \\
Tyr & $6 \cdot 4$ & $6 \cdot 9$ \\
Phe & $2 \cdot 1$ & $2 \cdot 6$ \\
His & $2 \cdot 5$ & $3 \cdot 0$ \\
Lys & 3.0 & $2 \cdot 9$ \\
Arg & $6 \cdot 0$ & $6 \cdot 2$ \\
\hline
\end{tabular}

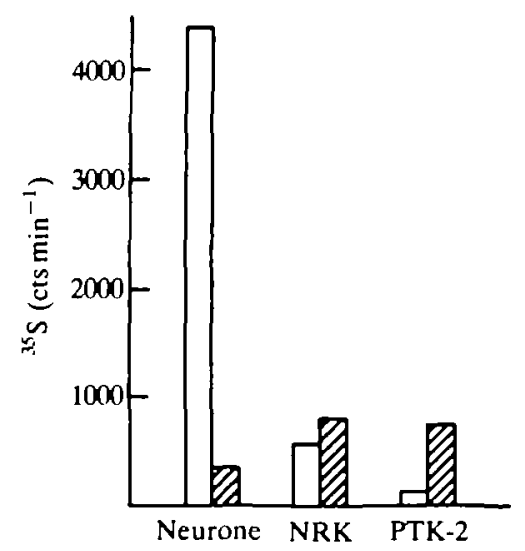

Fig. 9. Quantification of MAP-1B-related antigens in cell extracts. Whole cell extracts from $\left[{ }^{35} \mathrm{~S}\right]$ methionine-labelled rat brain neurones, NRK and PTK- 2 cells containing the same TCA-precipitable radioactive counts were subjected to immunoprecipitation with the polyclonal antibody 81 . The immunoprecipitates were fractionated by SDS-PAGE in a $6 \%$ polyacrylamide gel containing $4 \mathrm{M}$-urea. The $325 \mathrm{~K}$ and $220 \mathrm{~K}$ protein bands were cut out from the gel, and their associated radioactivity was determined in a scintillation spectrophotometer. White histograms represent data for the $325 \mathrm{~K}$ protein and striped histograms represent data for the $220 \mathrm{~K}$ protein.

their different cell locations, the $325 \mathrm{~K}$ and $220 \mathrm{~K}$ proteins have different peptide maps.

Limited proteolysis of both proteins with $S$. aureus V8 protease performed as described by Hernández et al. (1988) results in different peptide patterns (not shown). Exhaustive trypsin proteolysis also yields different peptide patterns for the $325 \mathrm{~K}$ and the $220 \mathrm{~K}$ protein (Fig. 10).

To test for similarities between the $325 \mathrm{~K}$ and $220 \mathrm{~K}$ proteins with neural MAP-1B, a primary culture of rat neurones was labelled with $\left[{ }^{35} \mathrm{~S}\right]$ methionine, MAP-1B was isolated by immunoprecipitation, exhaustively digested with trypsin and subjected to HPLC chroma-
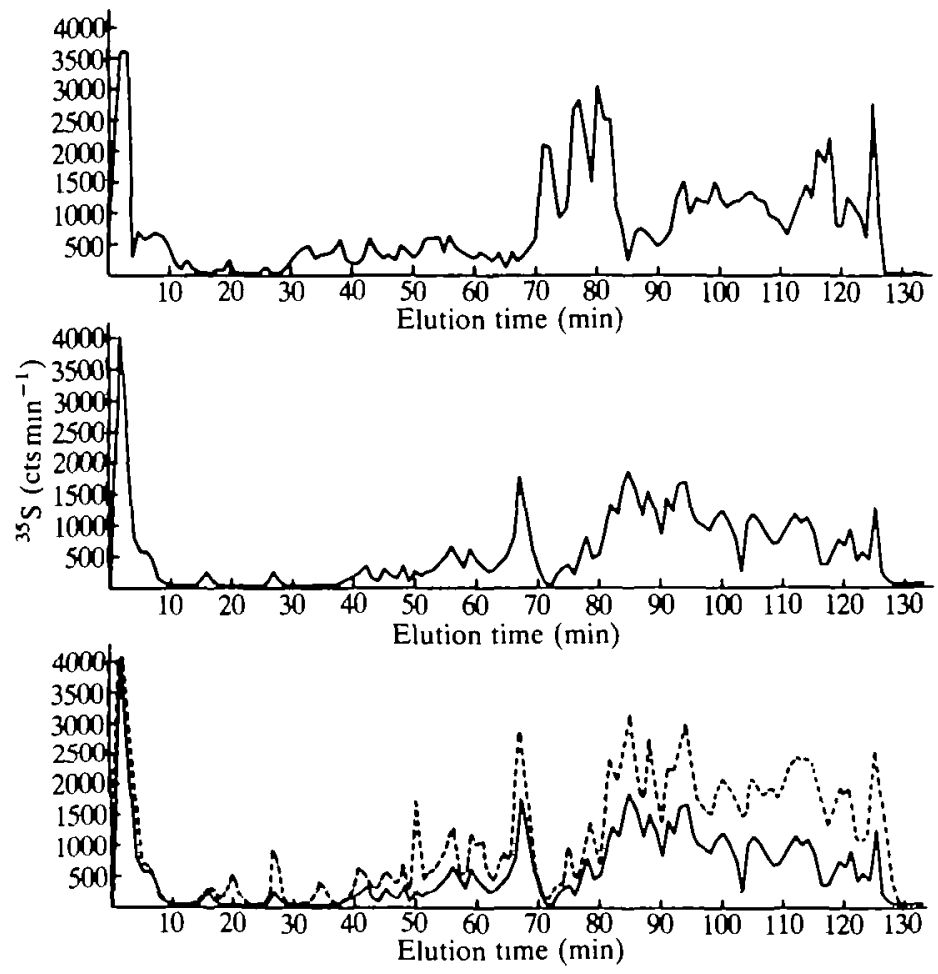

Fig. 10. HPLC analyses of tryptic peptides from the nonneural MAP-1B-related antigens and neural MAP-1B. $\left[{ }^{35} \mathrm{~S}\right]$ methionine-labelled proteins were digested exhaustively with trypsin and the resulting peptides were fractionated by HPLC as described in Materials and methods. A. The peptide patterns for the $220 \mathrm{~K}$ protein from NRK cells; $\mathrm{B}$, that for the $325 \mathrm{~K}$ proten from NRK cells; and $\mathrm{C}$, comparison of the peptide patterns of the $325 \mathrm{~K}$ protein from NRK cells and neural MAP-1B.

tography. Fig. 10 also shows that the proteolytic pattern of brain MAP-1B is very similar to that of the $325 \mathrm{~K}$ protein, and clearly different from that of $220 \mathrm{~K}$ protein.

Although brain MAP-1B and the $220 \mathrm{~K}$ nuclear protein seem to be structurally different, they are related immunologically, as previously indicated. To analyse the extent of such homology, a limited proteolysis of both proteins was performed. The digested peptides were fractionated by electrophoresis, blotted onto nitrocellulose paper and their reaction with the polyclonal antibody 81 was tested. Fig. 11 shows the presence of peptides of similar size reacting with the antibody in both MAP-1B and p220, which may suggest the presence of a common region shared by these proteins.

Differential phosphorylation of MAP-1B-related proteins in non-neural cells

Since it has been shown that neural MAP-1B is a phosphoprotein (Aletta et al. 1988; Díaz-Nido et al. 1988 ), we tested whether or not the $325 \mathrm{~K}$ and/or the $220 \mathrm{~K}$ protein could also be modified post-translationally. Incubation of an NRK culture with ${ }^{32} \mathrm{PO}_{4}$ results in the extensive phosphorylation of the $325 \mathrm{~K}$ protein and in a slight labelling of the $220 \mathrm{~K}$ protein (Fig. 12). To test whether the phosphorylation that takes place in $325 \mathrm{~K}$ protein was similar to that of brain MAP-1B, we com- 


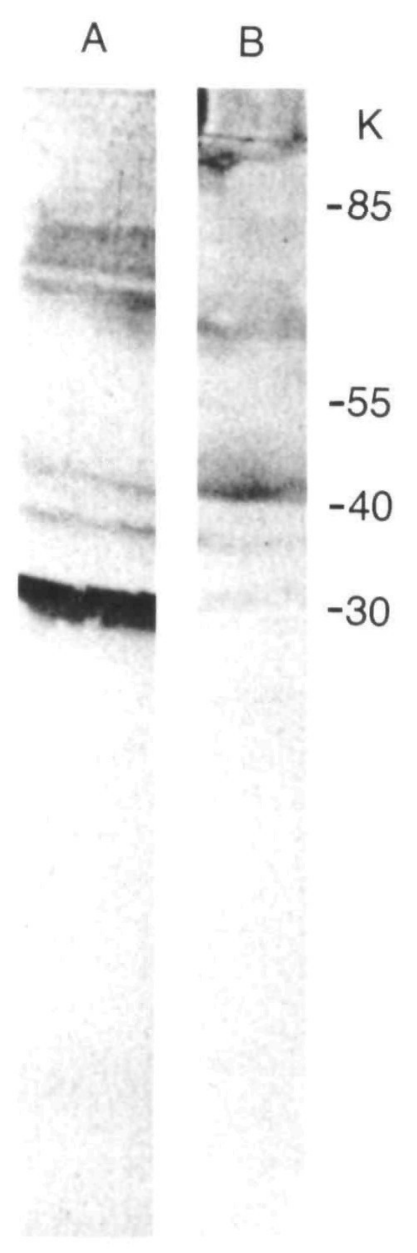

Fig. 11. Comparison of the peptides derived from brain MAP-1B and the $220 \mathrm{~K}$ nuclear protein that are recognized by the polyclonal antibody 81 . Both a rat brain MAP preparation and a soluble rat liver nuclear fraction were subjected to limited proteolysis with $\alpha$-chymotrypsin as described in Materials and methods. The resulting peptides were fractionated by SDS-PAGE in a $18 \%$ polyacrylamide gel and transferred to nitrocellulose paper. Peptides reacting with the polyclonal antibody 81 were revealed by immunoblotting. A. The peptides derived from brain MAP-1B, and B, those derived from the $220 \mathrm{~K}$ nuclear protein that are recognized by the polyclonal antibody to MAP-1B (81).

pared the phosphopeptide maps obtained after $S$. aureus V8 protease digestion of brain MAP-1B (phosphorylated in primary cultures of rat neurones or after intracranial injection of ${ }^{32} \mathrm{PO}_{4}$ ) and of the non-neural $325 \mathrm{~K}$ protein (phosphorylated after addition of ${ }^{32} \mathrm{PO}_{4}$ to a NRK culture). Fig. 13 shows an almost identical peptide pattern for both phosphoproteins. These results further suggest that the non-neural $325 \mathrm{~K}$ protein is structurally similar to neural MAP-1B. However, the $325 \mathrm{~K}$ protein is phosphorylated to a lesser extent than brain MAP-1B. Thus, the ${ }^{32} \mathrm{PO}_{4}$ counts associated with the immunoprecipitated $325 \mathrm{~K}$ protein account for approximately $0.1-0.5 \%$ of the total trichloroacetic acid (TCA)-precipitable cts $\min ^{-1}$ of the cell extract in both NRK and human skin fibroblasts, a value similar to that found for undifferentiated proliferating neuroblastoma cells (Díaz-

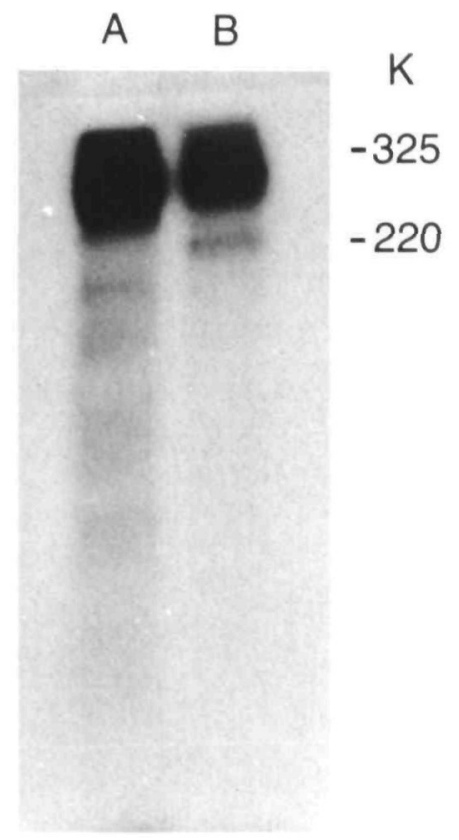

Fig. 12. Phosphorylation of non-neural MAP-1B-related antigens. A whole cell extract of NRK cells labelled with ${ }^{32} \mathrm{PO}_{4}$ was immunoprecipitated with antibodies 81 and 100 , and the corresponding immunoprecipitates were fractionated by SDS-PAGE. A. The immunoprecipitate obtained with antibody 100; and B, that obtained with antibody 81 .

Nido et al. 1988), whereas the ${ }^{32} \mathrm{PO}_{4}$ counts associated with brain MAP-1B in extracts from primary cultures of rat brain cells, or in brain extracts upon intracranial injection of ${ }^{32} \mathrm{PO}_{4}$, is about $1.5 \%$ of the TCA-precipitable cts $\min ^{-1}$, a value close to that found for differentiated neuroblastoma cells (Díaz-Nido et al. 1988).

\section{Binding of non-neural MAP-IB-related proteins to tubulin}

As immunofluorescence data and cell fractionation studies indicate that the $325 \mathrm{~K}$ protein is associated with microtubules and the $220 \mathrm{~K}$ protein binds to mitotic spindle microtubules, the binding of these proteins to tubulin in vitro has been analysed by an overlay assay that does not require large amounts of purified native protein. Fig. 14 shows that both the $325 \mathrm{~K}$ and the $220 \mathrm{~K}$ proteins bind to tubulin.

The binding of the $220 \mathrm{~K}$ protein to tubulin has also been analysed by copolymerization assays using a preparation of MAP-depleted tubulin obtained by phosphocellulose chromatography (which contains a small amount of MAP-2) and a preparation of subtilisincleaved tubulin that lacks the $4 \mathrm{~K}$ carboxy-terminal peptide responsible for the binding of MAPs (Serrano et al. 1984, 1985). Fig. 15 shows that the $220 \mathrm{~K}$ protein is associated with taxol-assembled tubulin, in the same way as brain MAPs, whereas it does not associate with subtilisin-cleaved tubulin.

\section{Discussion}

Brain microtubule-associated protein MAP-1 is com- 
A

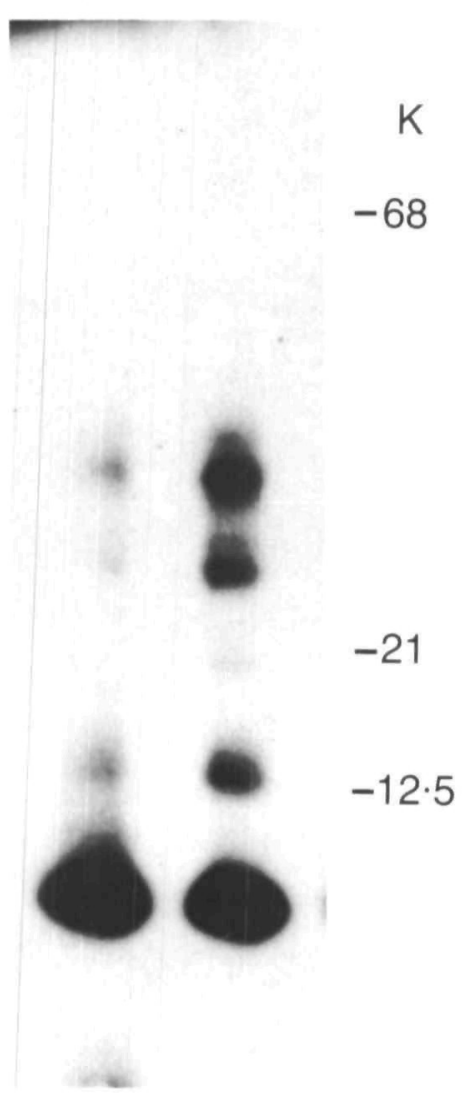

Fig. 13. Phosphopeptide mapping of the non-neural $325 \mathrm{~K}$ protein from NRK cells (A) and of neural MAP-1B (B). Both the $325 \mathrm{~K}$ protein from NRK cells labelled with ${ }^{32} \mathrm{PO}_{4}$ and the neural MAP-1B obtained after intracranial injection of ${ }^{32} \mathrm{PO}_{4}$ were obtained by immunoprecipitation with the antibody 100 , and digested with $2 \%$ S. aureus V8 protease, as described in Materials and methods. Molecular weight standards are bovine serum albumin $(68 \mathrm{~K})$, trypsin inhibitor $(21 \mathrm{~K})$ and cytochrome $c(12 \cdot 5 \mathrm{~K})$.

posed of at least two different polypeptides, MAP-1A (also called MAP-1.1) and MAP-1B (also called MAP$1.2, \operatorname{MAP}-1(x)$ and MAP-5), which are among the main components of the neuronal cytoskeleton (Bloom et al. 1985; Matus, 1988; Vallee \& Bloom, 1984; Vallee et al. 1986). In this study, we have analysed the presence of proteins related to brain MAP-1B in non-neural cells. Previous studies indicate that MAP-1B, as well as MAP$1 \mathrm{~A}$, is widely distributed outside the brain (Bloom et al. 1985; Vallee \& Bloom, 1984; Vallee et al. 1986), although some authors claim that MAP-1B immunoreactivity is found only in neurones (Calvert \& Anderton, 1985; Riederer et al. 1986; Matus, 1988). These conflicting reports may result from the use of monoclonal antibodies recognizing different isoforms of the same molecule or particular epitopes showing a cell-specific accessibility. Using monospecific polyclonal antibodies, in addition to several monoclonal antibodies, we have confirmed that MAP-1B is widely distributed in brain, in both neurones and glial cells, although it is more abundant in neurones, particularly within axon-like processes.
A

Fig. 14. Binding to tubulin of non-neural MAP-1B-related antigens and of neural MAP-1B. A cytoplasmic fraction and a nuclear fraction from NRK cells were immunoprecipitated with antıbody 81 . The corresponding immunoprecipitates were fractionated in a $5 \%$ polyacrylamide gel containing $4 \mathrm{M}$ urea, transferred to nitrocellulose paper and incubated with tubulin as described by Kremer et al. (1988). Bound tubulin was identified by monoclonal antibodies to $\alpha$ - and $\beta$-tubuln (Amersham). A. The immunoprecipitate from the NRK cytoplasmic fraction probed with tubulin; and $B$, the immunoprecipitate from the NRK nuclear fraction probed with tubulin. As controls, nitrocellulose paper not incubated with tubulin was incubated with antibodies to tubulin, and showed no reaction.

Furthermore, MAP-1B-related antigens also appear in all the non-neural cell lines tested.

Our immunofluorescence and cell fractionation studies show that non-neural cells contain two proteins immunologically related to brain MAP-1B, a $325 \mathrm{~K}$ protein, which is associated with the microtubule network and the MTOC, and a $220 \mathrm{~K}$ protein, which is localized in the nuclear matrix in interphase cells and is bound to mitotic spindle microtubules in dividing cells.

The presence in non-neural cells of brain MAP-related proteins localized not to the microtubule network but to the nuclei had been previously reported (Asai et al. 1985; Bonifacino et al. 1985; De Mey et al. 1984; Sato et al. 1983). It had been suggested that these nuclear proteins were immunologically related to brain MAP-1, but their precise relationship with either MAP-1A or MAP-1B remain to be established. Our results show that a $220 \mathrm{~K}$ nuclear protein, immunologically related to brain MAP- 


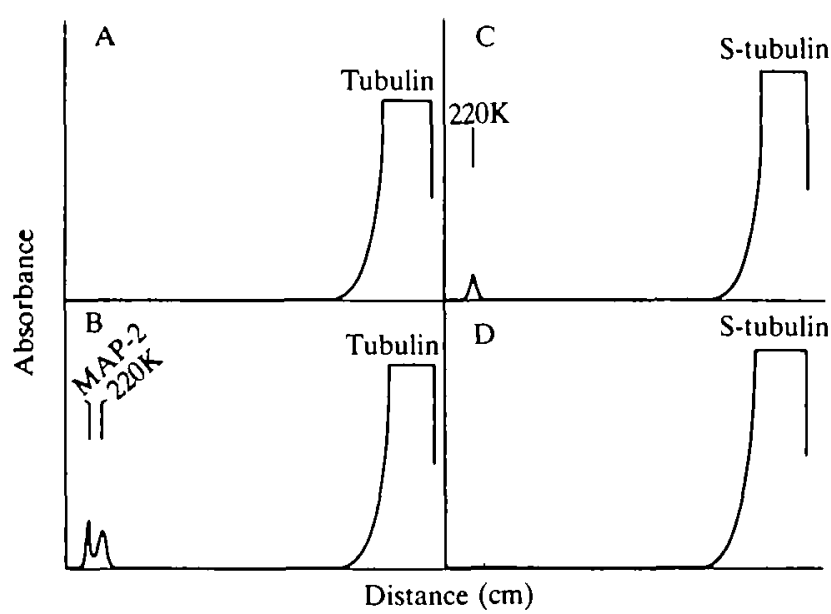

Fig. 15. Binding of the $220 \mathrm{~K}$ protein to tubulin polymers. The immunoprecipitate from a nuclear fraction was subjected to gel filtration in a Sepharose 2B-CL column in buffer A containing $0.1 \%$ SDS. The void volume contained the purified $220 \mathrm{~K}$ protein, which was then renatured after extensive dialysis against a suspension of Bio-Rad AD11A8 resin in buffer $A$. The $220 \mathrm{~K}$ protein was incubated with taxol-assembled tubulin or subtilisin-digested tubulin. Polymerized protein was separated by centrifugation in a Beckman airfuge and subjected to SDS-PAGE. The figure shows the densitometric scanning of the Coomassie Bluestained gels corresponding to the soluble $(A, C)$ and the polymerized (B,D) protein obtained upon incubation of the $220 \mathrm{~K}$ protenn with either tubulin assembled in the presence of taxol (A,B) or subtilisin-digested tubulin (S-tubulin) assembled in the presence of taxol (C,D). The positions of MAP-2, present in a small amount in the preparation of phosphocellulose-purified tubulin, and that of the $220 \mathrm{~K}$ protein are indicated.

$1 \mathrm{~B}$, is widely distributed in non-neural cells. This protein may be responsible for the nuclear staining observed with other antibodies to MAP-1 previously tested by other authors. For example, the monoclonal antibody to MAP. $1 \mathrm{~B}, 8 \mathrm{D} 12$, used by Bonifacino et al. (1985) reacts with the same $220 \mathrm{~K}$ protein that is recognized by our polyclonal antibodies to MAP-1B, and only reacts with MAP$1 \mathrm{~B}$ in microtubule protein (unpublished results). However, these data do not eliminate the possibility that other nuclear proteins might have epitopes in common with MAP-1A that the antibodies used in this study just happen not to recognize. In fact, some antibodies to MAP-1 appear to react with kinetochores and prekinetochores (De Ney et al. 1984), thus differing from the pattern found for the MAP-1B-related $220 \mathrm{~K}$ nuclear protein here reported.

The MAP-1B-related nuclear protein differs from brain MAP-1B in several respects: (1) it is not recognized by some antibodies to brain MAP-1B; (2) it has a different cellular and subcellular distribution from that expected for a MAP, as it is more abundant in non-neural cells than it is in neurones, and is mainly localized in the nuclear matrix rather than being associated with cytoplasmic microtubules in interphase cells; (3) it has a different electrophoretic mobility from brain MAP-1B; (4) its peptide pattern after proteolytic digestion is different from that found for brain MAP-1B, although we cannot rule out the presence of a common domain shared by these proteins; and (5) it appears to be phosphorylated to a lesser extent than the MAP-1B-related $325 \mathrm{~K}$ protein present in non-neural cells.

On the other hand, the $325 \mathrm{~K}$ protein found in nonneural cells is extremely similar to brain MAP-1B in the following respects: (1) it reacts with all antibodies to brain MAP-1B tested; (2) it is associated with microtubules and with the MTOC, as can be expected for a MAP; (3) it has the same abnormal electrophoretic mobility as brain MAP-1B; (4) it has a peptide pattern after proteolytic digestion that is similar to that found for brain MAP-1B; and (5) it has also a similar phosphopeptide pattern to that of brain MAP-1B; although it is phosphorylated to a level comparable to that found in undifferentiated, proliferating neuroblastoma cells, which is lower than that found in differentiated neuronal cells. Given the similarities between neural MAP-1B and the non-neural $325 \mathrm{~K}$ protein, it can be assumed that both are the same protein or closely related isoforms of the same molecule.

Immunocytochemical data suggest that neurones contain a greater amount of the $325 \mathrm{~K}$ protein (MAP-1B) than of the $220 \mathrm{~K}$ protein when compared to non-neural cells. This possibly reflects differences in the roles played by these two proteins.

From their distinctive features, it can be speculated that the non-neural $220 \mathrm{~K}$ and $325 \mathrm{~K}$ proteins related to brain MAP-1B may perform different functions within the cell. The binding of both proteins to tubulin in vitro lends support to the view that these proteins may regulate the state of microtubule assembly during the cell cycle. The presence of the $325 \mathrm{~K}$ protein in the MTOC raises the possibility that it is implicated in the nucleation of microtubule assembly in vivo. Whereas the $325 \mathrm{~K}$ protein can be considered a MAP because of its binding to microtubules (and the MTOC) during the cell cycle, the $220 \mathrm{~K}$ protein can be considered to be a SAP (spindleassociated protein), by virtue of its unique association with the microtubules of the mitotic spindle.

The molecular mechanisms responsible for the association of the $220 \mathrm{~K}$ protein with the nuclear matrix in interphase cells and for its binding to mitotic spindle microtubules remain to be determined. The $220 \mathrm{~K}$ protein is synthesized in the cytoplasm during interphase, and preliminary results indicate that it migrates into the nucleus by an active transport mechanism. In the nucleus, it is bound to the ribonucleoprotein particles that constitute the nuclear matrix. At the onset of mitosis, the $220 \mathrm{~K}$ protein might be dissociated from RNPs and, when the nuclear envelope breaks down, it would participate in the formation of the mitotic spindle. Perhaps the phosphorylation of the $220 \mathrm{~K}$ protein may play a role in this process, as it has been reported that phosphorylation of MAP-1B polypeptides may favour their association with microtubules (Díaz-Nido et al. 1988). Furthermore, it has been observed that centrosomes are able to organize the mitotic spindle only after nuclear envelope breakdown (Armas-Portela et al. 1988; Vandre et al. 1984a,b). This transformation has. been partly ascribed to the 
binding of nuclear phosphoproteins (Vandre et al. $1984 a, b)$. Thus, it is possible that the $220 \mathrm{~K}$ protein is one of these proteins. The observed binding of the $220 \mathrm{~K}$ protein to tubulin in vitro supports this view. On the other hand, the phosphorylation of centrosomal proteins related to $\mathrm{MAPs}$, such as the $325 \mathrm{~K}$ protein related to MAP-1B reported in this study, may also favour the increase in the microtubule-nucleating ability of centrosomes observed at the beginning of mitosis (Vandre $e t a l$. $1984 a, b)$. It remains to be established what relationship, if any, exists between this MAP-1B-related $325 \mathrm{~K}$ protein and other MAP-related phosphoproteins found in nonneural cells by other authors (Vandre et al. 1984b, 1986; Sato et al. 1985).

In conclusion, non-neural cells contain at least two different tubulin-binding proteins related to neural MAP-1B, which may favour the promotion and/or stabilization of microtubule assembly in vivo. The $325 \mathrm{~K}$ protein (which is the non-neural counterpart to neural MAP-1B) would perform such a role during the entire cell cycle, whereas the association of the $220 \mathrm{~K}$ protein to microtubules would be restricted to mitosis.

We thank Dr R. B. Vallee (Worcester Foundation for Experimental Biology, Shrewsbury, MA) for the generous gift of antibodies 1B-1 and 1B-3. We also acknowledge Dr Suffness (National Products Branch, National Cancer Institute, Bethesda, MD) for generously providing taxol.

We are also grateful to Dr E. Méndez for amino acid analysis, to L. Kremer for tubulin overlay assays, and to R. Padilla for technical assistance.

This work was supported by Grants from Comision Asesora para el Desarrollo de Investigación Científica y Técnica and the United States-Spain Joint Committee for Scientific and Technological Cooperation.

\section{References}

Aletta, J. M., Lewis, S. A, Cowan, N. J. \& Greene, L. A. (1988). Nerve growth factor regulates both the phosphorylation and steady-state levels of microtubule-associated protein 1.2 (MAP 1.2). J. C'ell. Biol. 106, 1573-1581.

armas-Portela, R., Paweletz, N., Zimmermann, H.-P. \& Ghosh, $S$. (1988). Microtubule rearrangements during mitosis in multinucleate cells. Cell Motil. Cytoskel. 9, 254-263.

Artlieb, U., Krepler, R. \& Wiche, G. (1985). Expression of microtubule-associated proteins, MAP-1 and MAP-2, in human neuroblastomas and differential diagnosıs of immature neuroblasts. Lab. Invest. 53, 684-691.

Asal, D. J., Thompson, W. C., Wilson, L., Dresden, C. F., Schulman, H. \& Purich, D. L. (1985). Microtubule-associated proteins (MAPs): a monoclonal antibody to MAP-1 decorates microtubules in vitro but stains stress fibers and not microtubules in vitm. Proc. natn. Acad. Sci. U.S.A. 82, 1434-1438.

Bloom, G. S., Luca, F. C. \& Vallee, R. B. (1985). Microtubuleassociated protein 1B: identification of a major component of the neuronal cytoskeleton. Proc, natn. Acad. Sci. U.S.A. 82, 5404-5408.

Bonifacino, J. S., Klausner, R. D. \& Sandoval, I. V. (1985). A widely distributed nuclear protein immunologically related to the microtubule-associated protein MAP-1 is associated with the mitotic spindle. Proc. natn. Acad. Sci. U.S.A. 82, 1146-1150.

Calvert, R. \& Anderton, B. H. (1985). A microtubule-associated protein, MAP-l(X), which is expressed at elevated levels during development of rat cerebellum. EMBO J. 4, 1171-1176.

Cleveland, D. W., Fisher, S. G., Kirschner, M. W. \& Laemmli, U. K. (1977). Peptide mappıng by limited proteolysis in sodium dodecyl sulfate and analysis by gel electrophoresis. 7. biol. Chem. 252, 1102-1106

De Mey, J., Aerts, F., Moeremans, M., Gevens, G., Dancels, G. \& De Brabander, M. (1984). Anti-MAP 1 reacts with the centrosomes, kınetochores, midbody and spindle of mitotic PTK-2 cells. J. Cell Biol. 99, 447a (abstract).

Dlaz-Nido, J., Serrano, L., Méndez, E. \& Avila, J. (1988). A casein kinase II-related activity is involved in phosphorylation of microtubule-associated protein MAP-1B during neuroblastoma cell differentiation. 7. Cell Biol. 106, 2057-2065.

Fairbanks, G., Steck, N. C. \& Wallach, D. F. (1981). Electrophoretic analysis of the major polypeptides of the human erythrocvte membrane. Biochemistry 10, 2606-2617.

Hernández, M. A., Avila, J. \& Andreu, J. M. (1986)

Physicochemical characterization of microtubule-associated protein MAP-2. Eur. 7. Biochem 154, 41-48.

Hernández, M. A., Padilla, R. \& Avila, J. (1988). Iodination of proteins on nitrocellulose blotting paper. F. biochem. biophys. Ileth. $16,17-26$

Herrmann, H., Dulton, M. S. \& Wiche, G. (1985).

Microheterogeneity of microtubule-associated proteins, MAP-1 and MAP-2, and differential phosphorylation of individual subcomponents. 7. biol. Chem. 260, 5795-5803.

Kremer, L., Dominguez, J. \& Avila, J. (1988). An overlay assay to test for tubulın-binding proteins. Analy. Biochem. 175, 91-95.

LAEMMLI, U. K. (1970). Cleavage of structural proteins during the assembly of the head of bacteriophage T4. Nature, Lond. 227 680-685

LuCA, F. C., Bloom, G. S. \& Vallee, R. B. (1986). A monoclonal antibody that cross-reacts with phosphorylated epitopes on two microtubule-associated proteins and two neurofilament polypeptides. Proc. natn. Acad. Sci. U.S.A. 83, 1006-1010.

Matus, A. (1988). Microtubule-associated proteins: their potential role in determining neuronal morphology. A Rev. Neurosci. 11, 29-44.

Montejo de Garcini, E., Diez, J. C. \& Avila, J. (1986). Quantitation and characterization of tau factor in porcine tissues. Biachim. brophys. Acta 881, 456-461.

Murphy, D. B. \& Borisy, G. G. (1975). Assocration of high molecular weight proteins with microtubules and their role in microtubule assembly in vitro. Proc. "Iat". Acad. Sci. L.S.A. 72 2696-2700.

Olmsted, J. B. (1986). Microtubule-associated proteins. A. Rez. Cell Biol. 2, 421-457.

Riederer, B., Cohen, R. \& Matus, A. (1986). MAP-5: a novel brain microtubule-associated protein under strong developmental regulation. 7. Neurocytol. 15, 763-775.

Sato, C., Nishizawa, K., Nakamura, H., Komagoe, Y., Shimada, K., VEDA, R. \& SUzUKı, S. (1983). Monoclonal antibody against microtubule-associated protein MAP-1 produces immunofluorescent spots in the nucleus and centrosome of cultured mammahan cells. Cell Struct. Funct. 8, 245-254.

Sato, C., Nishizawa, K., Nakayama, T. \& Kobayashi, 'T. (1985). Effect upon mitogenı-stımulation of calcium-dependent phosphorylation of cytoskeleton-associated 350,000- and 80,000mol-wt polypeptides in quiescent $3 \mathrm{Y} 1$ cells. 7 . Cell Biol. 100 , $748-753$

Serrano, L., Avila, J. \& Maccioni, R. B. (1984). Controlled proteolysis of tubulin by subtilisin: localization of the site for MAP-2 interaction. Biochemistry 23, 4675-4681.

Serrano, L., Montejo, E., Hernández, M. A. \& Avila, J. (1985). Localızation of the tubulin binding site for tau protein. Eur. $Y$. Biochem. 153, 595-600.

Shelanski, M. L., Gaskin, F. \& Cantor, C. R. (1973). Microtubule assembly in the absence of added nucleotides. Proc. natn. Acad. Sci. U.S.A. 70, 765-768.

Sherline, P. \& MASCARDO, R. N. (1982). Epidermal growth factor induces rapid centrosomal separation in HeLa and 3T3 cells. $\mathcal{~}$. Cell Biol 93, 507-511.

Smith, H. C., Ochs, R. L., Fernandez, E. A. \& Spector, D. L. (1986). Macromolecular domains containıng nuclear protein p107 and U-Sn RNP protein $\mathrm{p} 28$, further evidence for an in situ nuclear matrix. Molec. cell. Biochem. 70, 151-168.

SPECTOR, D. L. \& SMITH, H. C. (1986). Redistribution of U-snRNPs 
durıng mitosis. Expl Cell Res. 163, 87-94.

Towbin, H., Staehelin, T. \& Gordon, J. (1979). Electrophoretic transfer of proteins from polyacrylamide gels to nitrocellulose sheets: procedure and some applications. Proc. natn. Acad. Sci. C.S.A. 76, 4350-4354.

Valdivia, M. M., Avila, J., Coll, J., Colaço, C. \& Sandoval, I. V. (1982). Quantitation and characterization of the microtubuleassociated protein MAP-2 in porcine tissues and its isolation from porcine and human cell lines. Biochem. biophys. Res. Commun. $105,1241-1249$.

VALLEE, R. B. \& BLOOM, G. S. (1984). High-molecular-weight microtubule-associated proteins. Molec. cell. Biol. 3, 21-75.

Vallee, R. B., BLoom, G. S. \& LuCA, F. C. (1986). Differential structure and distribution of the high molecular weight microtubule-associated proteins, MAP-1 and MAP-2. Ann. N.Y. Acad. Sci. 466, 134-144.

VANDRE, D. D., Davis, F. M., RAO, P. N. \& Borisy, G. G. (1984b). Phosphoprotens are components of mitotic microtubuleorganizing centers. Proc. natn. Acad. Sci. U.S.A. 81, 4439-4443.

VANDre, D. D., Davis, F. M., Rao, P. N. \& Borisy, G. G. (1986). Distribution of cytoskeletal proteins sharing a conserved phosphorylated epitope. Eur. J. Cell Biol. 41, 72-81.
VANDRE, D. D., Kronesbuch, P. \& Borisy, G. G. (1984a). Interphase-mitosis transition: microtubule rearrangements in cultured cells and sea urchin eggs. In Molecular Biology of the Cytoskeleton (ed. G. G. Borisy, D. W. Cleveland \& D. B. Murphy), pp. 3-16. New York: Cold Spring Harbor.

Verhejen, R., Kunjers, H., Voous, P., Van Venroou, W. \& Ramaekers, F. (1986). Distribution of the $70 \mathrm{~K}$ U1 RNAassociated protein during interphase and mitosis. Correlation with other U RNP particles and protens of the nuclear matrix. 7. Cell Sci. 86, 173-190.

Weingarten, M. D., Lockwood, M. H., Hwo, S. Y. \& KirsCHNeR, M. W. (1975). A protein factor essential for microtubule assembly. Proc. natn. Acad. Sci. U.S.A. 72 $1858-1862$.

WICHE, G. (1985). High-molecular-weight microtubule-associated proteins: an ubiquitous family of cytoskeletal connecting lines. Trends Biochem. Sci. 10, 67-70.

(Received 18 August 1998 - Accepted, in revised forn, 2 Jamuary 